\title{
Citizenship and the Environment
}

Andrew Dobson

Oxford University Press, Oxford, 2003, 238pp.

ISBN: $0199258430 / 0199258449$.

Contemporary Political Theory (2005) 4, 473-475. doi:10.1057/palgrave.cpt.9300212

In this contribution to the debate about how to achieve a sustainable society, Andrew Dobson promotes the idea of 'ecological citizenship'. Following on from his previous book, Justice and the Environment (OUP, 1998), the focus on citizenship is a response to the question of what is it that motivates agents to do what justice requires. Although incentive-based policies may bring some success in harnessing individuals' self-interest to the ends of sustainability, they will not necessarily yield deep and lasting commitments to develop the more ecologically sustainable habits and practices that the realization of justice depends on. Dobson emphasises that people also sometimes do good, not just because external pressures are applied, but because they want to be virtuous. The book can be read as an extended reflection on how the desire to be virtuous can be fostered and encouraged.

In this respect, it is located within traditional political thought about what it means to be a good citizen. This question has been underplayed in modern liberal conceptions of citizenship, which emphasize the rights and entitlements of citizenship at the expense of duties and virtues. Although an emphasis on duties and virtue is more characteristic of republican conceptions, Dobson's central claim is that contemporary circumstances, especially those which characterize globalization, call forth an entirely new conception of citizenship.

The general circumstances of globalization, he observes, can be modelled in two different ways. One involves emphasizing 'interconnectedness' and regarding the world effectively as a global village in which everyone is increasingly networked together in a common enterprise. Dobson is highly critical of this view and endorses the alternative, which sees the reality of the processes of globalization as profoundly asymmetrical. Thus, rather than talk about how 'we' are globalizing, it is more appropriate to say that while some the rich of the world — are globalizing, others — the poor — are being globalized.

The processes of globalization call forth a cosmopolitan normative response, he believes, but the two contrasting takes on globalization yield different versions of cosmopolitanism. 'For the cosmopolitanism that builds on the interconnectedness view of globalization, the first virtue is often "equal and open dialogue". From a materialist, asymmetrical point of view, the first virtue is "more justice" (p. 21). The former view tends to take the cosmopolitan political community as being bound together by a 'commitment to open 
dialogue' and its task as being to 'create institutional frameworks which widen the boundaries of the dialogic community' (p. 23). Yet what, asks Dobson bluntly, 'will “open dialogue" tell us that we do not already know?' (p. 23). Take the Small Island States, that are threatened with disaster as a result of global warming, he says to illustrate the point, we already know well enough what they want: they: 'do not want to talk any more. What they want is for net contributors to global warming to reduce their impact on the global environment' (p. 25).

Dobson argues strongly for justice to take primacy over dialogue, and for those who are benefiting from globalization to recognize obligations to those who are suffering the ills generated by it. It is in these asymmetrical relationships that Dobson sees the real bonds of a new, 'postcosmopolitan', citizenship which issues in materially based obligations on those who have benefited as a result of harms suffered by the globally worse off, in social, economic and environmental terms. This form of citizenship does not depend on reciprocity, territoriality or even membership of a particular polity to generate its obligations.

This, of course, raises the question of what distinguishes the political virtues and obligations of ecological and postcosmopolitan citizenship specifically from the moral virtues and obligations of 'common humanity' more generally. It is a question that Dobson confronts in various contexts throughout the book, because it is critical for the more ambitious theoretical aspect of his project - namely, not only to show how citizens of existing polities can be more ecologically responsible, but how, in fact, what he is advocating is an entirely new form of citizenship. To follow him here requires an effort of imagination and a readiness to 'think outside the box' of conventional ideas of what constitutes citizenship as such. Doubtless, different readers will have different views on whether the new conception has sufficient affinities with more conventional understandings of citizenship to warrant using the same word.

To fix on semantic contestation, however, would be to miss the significance of the substantive normative argument advanced in this book. The fundamental claim is that the asymmetrical processes of globalization generate obligations of justice which ought to be the first virtue of citizens to recognize and seek to discharge. Justice requires each citizen to strive to live within his or her fair share of ecological space and to work so that her or his polity does likewise. If there is no immediately foreseeable possibility of a cosmopolity there are nonetheless the associations of global civil society, which can meanwhile continue to foster the sense of justice that ecological citizenship requires. Dobson also finds a place for ecological citizenship in liberal societies, and offers some quite detailed consideration of how ecological citizenship might be taught in British schools, given the currently propitious circumstances 
for it. Thus, in response to the question 'how do people become ecological citizens?', the book is rich in constructive substantive suggestions, which are rooted in a compelling view of what justice today requires.

Tim Hayward School of Social \& Political Sciences, University of Edinburgh, UK. 